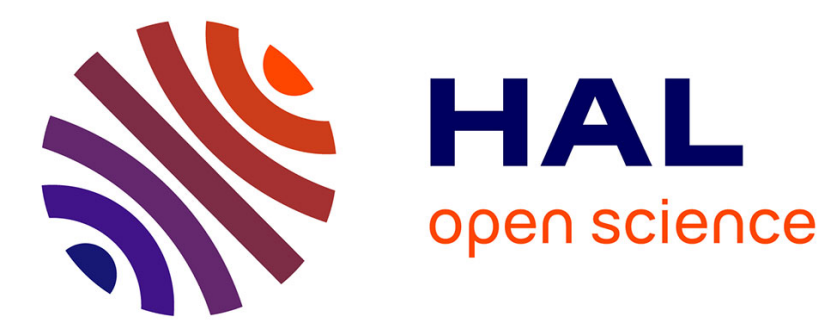

\title{
Assessment of sperm DNA integrity within the Palaemon longirostris (H. Milne-Edwards, 1837) population of the Seine estuary
}

Alexandre Erraud, Marc Bonnard, Olivier Geffard, Arnaud Chaumot, Aurélie Duflot, Alain Geffard, Joëlle Forget-Leray, Benoît Xuereb

\section{To cite this version:}

Alexandre Erraud, Marc Bonnard, Olivier Geffard, Arnaud Chaumot, Aurélie Duflot, et al.. Assessment of sperm DNA integrity within the Palaemon longirostris (H. Milne-Edwards, 1837) population of the Seine estuary. Environmental Pollution, 2019, 245, pp.485-493. 10.1016/j.envpol.2018.11.006 . hal-01918845

\section{HAL Id: hal-01918845 \\ https://hal.science/hal-01918845}

Submitted on 22 Nov 2018

HAL is a multi-disciplinary open access archive for the deposit and dissemination of scientific research documents, whether they are published or not. The documents may come from teaching and research institutions in France or abroad, or from public or private research centers.
L'archive ouverte pluridisciplinaire $\mathbf{H A L}$, est destinée au dépôt et à la diffusion de documents scientifiques de niveau recherche, publiés ou non, émanant des établissements d'enseignement et de recherche français ou étrangers, des laboratoires publics ou privés. 


\section{Accepted Manuscript}

Assessment of sperm DNA integrity within the Palaemon longirostris $(\mathrm{H}$. MilneEdwards, 1837) population of the Seine estuary

Alexandre Erraud, Marc Bonnard, Olivier Geffard, Arnaud Chaumot, Aurélie Duflot, Alain Geffard, Joëlle Forget-Leray, Benoit Xuereb

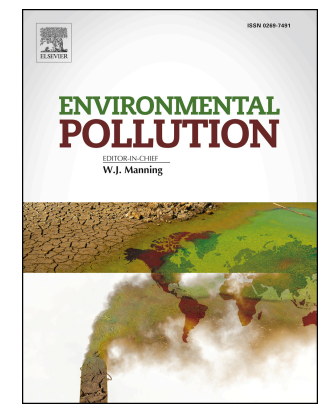

PII:

S0269-7491(18)33271-8

DOI:

https://doi.org/10.1016/j.envpol.2018.11.006

Reference: $\quad$ ENPO 11833

To appear in: Environmental Pollution

Received Date: 16 July 2018

Revised Date: 31 October 2018

Accepted Date: 2 November 2018

Please cite this article as: Erraud, A., Bonnard, M., Geffard, O., Chaumot, A., Duflot, Auré., Geffard, A., Forget-Leray, Joë., Xuereb, B., Assessment of sperm DNA integrity within the Palaemon longirostris (H. Milne-Edwards, 1837) population of the Seine estuary, Environmental Pollution (2018), doi: https:// doi.org/10.1016/j.envpol.2018.11.006.

This is a PDF file of an unedited manuscript that has been accepted for publication. As a service to our customers we are providing this early version of the manuscript. The manuscript will undergo copyediting, typesetting, and review of the resulting proof before it is published in its final form. Please note that during the production process errors may be discovered which could affect the content, and all legal disclaimers that apply to the journal pertain. 


\section{Assessment of sperm DNA integrity within the \\ 2 Palaemon longirostris $\quad$ (H. Milne-Edwards, 1837) \\ 3 population of the Seine estuary}

4 Alexandre Erraud ${ }^{1}$, Marc Bonnard ${ }^{2}$, Olivier Geffard ${ }^{3}$, Arnaud Chaumot ${ }^{3}$, Aurélie

5 Duflot $^{1}$, Alain Geffard ${ }^{2}$, Joëlle Forget-Leray ${ }^{1}$, Benoit Xuereb ${ }^{1 *}$

$6 \quad{ }^{1}$ Normandie Univ, UNIHAVRE, UMR-I 02 SEBIO, FR CNRS 3730 SCALE, 76600 Le Havre, France

$7 \quad{ }^{2}$ Université Reims Champagne Ardenne, UMR-I 02 SEBIO, 51100 Reims, France.

$8{ }^{3}$ IRSTEA, UR RiverLY Laboratoire d'écotoxicologie, centre de Lyon-Villeurbanne, F-69625 Villeurbanne,

9 France

$10 *$ Corresponding author

11 Email: benoit.xuereb@univ-lehavre.fr

Tel: +332328599 11; fax: +3323274 4505

\section{Abstract}

The interpretation of biomarkers in natura should be based on a referential of expected values in uncontaminated conditions. Nevertheless, to build a reference data set of biomarker responses in estuarine areas, which receive chronic pollution loads due to their transition position between continent and sea, is impossible. In this context, the aim of the present work was to propose the use of laboratory recovery period to define a baseline for the measurement of sperm DNA damage by Comet assay in the estuarine prawn Palaemon longirostris. For that, sperm DNA integrity was observed after both a passive (i.e. 20 days in a clean environment) and an active (i.e. forced renewal of spermatophores) recovery of wild $P$. longirostris specimens from the Seine estuary, in laboratory conditions. Then, the levels of sperm DNA damage recorded within the $P$. longirostris population of the Seine estuary, during six campaigns of sampling from April 2015 to October 2017 , have been interpreted according to the defined threshold values. The results showed a persistence in the level of DNA damage after 20-day in clean environment with the passive recovery. This strategy was inconclusive to reach a baseline level but it revealed the lack of DNA repair mechanisms. For the active recovery, a decrease of $54 \%$ of the level of DNA damage has been observed after the first renewal of spermatophores and this level stabilized after the second renewal. On the basis of this second strategy, we defined a mean basal value of sperm DNA damage of 54.9 A.U. and a maximum threshold of 69.7 A.U. (i.e. $95 \%$-CI). The analysis of the results using the reference value highlighted significant abnormal sperm DNA damage within the native population of $P$. longirostris from the Seine estuary on all stations during the six-sampling campaigns.

Key words: Comet assay, Biomonitoring, Baseline, Laboratory recovery, Crustaceans. 
1. Introduction

Estuaries are among the most productive ecosystems supporting a wide variety of species, many of which present a potential commercial interest (Menezes et al., 2006). These systems have a predominant role in many aspects of living organisms such as nursery, food zone and migratory route (Chapman and Wang, 2001). Nevertheless, due to their transitional position between continent and sea, the majority of estuaries are submitted to continual inputs of a large diversity of contaminants. Consequently, the assessment of transitional waterbodies quality and health status is an important issue which requires the development of operational biomonitoring methodologies.

Biomarkers are considered as relevant biomonitoring tools to establish causal relationships between the exposure to chemicals and the impacts on organisms, integrating the aspects of bioavailability and synergetic effect of chemical mixture (Hanson et al., 2010). They are starting to be considered in the regulatory framework of environmental surveys in Europe, as for example in the UE Marine Strategy Framework Directive (2008/56/EC). For many years, the major part of the in situ applications of biomarkers was based on the upstream/downstream approach involving the comparison between a reference and an impacted site (Flammarion and Garric, 1997; Flammarion et al., 2002). This approach has been well established and showed its relevance to assess the quality of sites presenting similar physicochemical parameters. However, estuarine ecosystems are subject to significant changes in physicochemical conditions at different spatial (e.g. upstream-downstream salinity gradient) and temporal scales (e.g. tidal flow) (Lobry et al., 2006), making the upstream/downstream comparisons unsuitable. More recently, the construction of a chronological and/or spatial reference within un-impacted population, integrating the natural variability as incertitude source (i.e. both intrinsic biotic and environmental factors), was proposed as a relevant strategy to establish baselines and threshold values for biomarker responses (Barrick et al., 2016; Hagger et al., 2008; Hanson et al., 2010; Jubeaux et al., 2012; Lacaze et al., 2011a; Xuereb et al., 2009). This approach allows the deployment and the interpretation of biomarkers on a large spatial scale, without having to refer in parallel to reference stations. If such levels of finalization have been achieved for some biomarkers in some marine and freshwater species (e.g. Coulaud et al., 2011; Erraud et al. 2018; Lacaze et al., 2011a; ICES, 2011; Xuereb et al. 2009), they are particularly difficult to reach in estuarine species. This statement is due in large extent to the difficulties to characterize a reference station in open systems submitted to the pollutant discharges in the up-stream part of their watersheds. On the other hand, direct comparisons between native populations of exclusively estuarine species from different estuaries must be done with care the influence of different adaptive mechanisms (Rank et al., 2007). 
It is however a great concern to deal with such difficulties in order to propose methodologies allowing to assess the health of organisms inhabiting these important ecosystems. An alternative strategy based on the restoration of a basal response after a recovery phase in laboratory healthy conditions has been demonstrated as suitable to determine references for some biomarkers (e.g. EROD, DNA integrity of somatic cells) in the black see bream, Acanthopagrus butcheri (Webb and Gagnon, 2013). The relevance of this approach should be investigated for other biomarker/species combinations.

The Seine estuary (France) is considered as one of the most polluted estuaries in Europe, subject to an important anthropogenic pressure due to its location at the outlet of the Seine watershed (Burgeot et al., 2017; Cachot et al., 2006; Carpentier et al., 2002; Meybeck et al., 2004). The Seine basin represents a territory of $78600 \mathrm{~km}^{2}$ and welcomes more than a quarter of the French population (Dévier et al., 2013). In addition to the Parisian metropole, the Seine estuary receives anthropogenic pressure from two major nearshore agglomerations and major harbours (i.e. Rouen and Le Havre); four major industrial areas (i.e. Elbeuf, Rouen, Port Jérôme and Le Havre); and many agricultural areas bordering the Seine River. The perpetual chemical overflow of contaminants of the Seine River, added to the remobilisation of contaminants linked with the hydro-sedimentary function, the maritime and fluvial traffic which requires a daily dredging, the industrial past and the important intake of the upstream watershed of this estuary together make this estuary largely affected by a wide range of contaminants (Cailleaud et al., 2007a, b). This estuary is therefore particularly prone to genotoxic pressure since the Seine River receives inputs of a large variety of micro-pollutants such as polycyclic aromatic hydrocarbons (PAH) (Motelay-Massei et al. 2007), trace metals (Grosbois et al. 2006) and polychlorinated biphenyls (PCB) (Meybeck et al. 2004).

Genotoxic biomarkers are considered as integrative tools, able to provide complementary informations to chemical and ecological analyses in field monitoring (Lacaze et al., 2011a). Indeed, the study of genotoxicity represents a major challenge for the environment preservation due to the wide range of genotoxic substances (i.e. more than a third of the anthropogenic compounds released into the aquatic environment), and their environmental impact and the possible ecological consequences, particularly on the survival and the renewal of certain wild populations (Claxton et al., 1998; Ohe et al., 2004). For these reasons, genotoxic assessment in the Seine estuary has started in the 2000s and has been the focus of Research until now. In spite of the diversity of genotoxic compounds, only PAHs have been extensively investigated in the Seine estuary, and majority of works were based on bioassays assessesing the genotoxicity potential of sediments or suspended particulate matter using bacterial strain, cell lines (i.e. SOS Chromotest and Ames test) or exotic species (Barjhoux et al., 2012; 
Vicquelin et al., 2011; Vincent-Hubert et al., 2017). Up until now, only few studies measured genotoxic effects in somatic cells of indigenous organisms living in the Seine estuary such as the flounder Platichtys flesus (Marchand et al., 2004) and the mussels Dreisseina polymorpha for the upstream part and Mytilus edulis for the mouth part of the estuary (Rocher et al. 2006, Le Goff et al. 2006). Moreover, no crustacean group has been investigated in the Seine River in spite of its ecological and ecotoxicological interest.

Among crustaceans, Palaemon longirostris (Milne Edwards, 1937) is a typical estuarine species that completes its whole life cycle in brackish water (González-Ortegón et al., 2006), which is present from the north of Africa up to Western Germany and North-East England (view in Béguer et al., 2009). Palaemon longirostris is the most common and abundant prawn in the Seine estuary, as in other large estuaries of the Atlantic French coast.

In this context, the global aim of our study consists in the development of Comet assay on Palaemonid prawns spermatozoa to assess the potentiality of the sperm DNA integrity to be proposed as a relevant biomarker for the surveys of European coastal and estuarine water bodies. Our investigation focuses on spermatozoa since they are in most cases considered to be sensitive to contamination due to their inability to prevent oxidative stress and to repair DNA damage (Aitken et al., 2004). In addition, assessment of genotoxicity on this cellular type is of obvious interest regarding its key role in reproduction success (Lacaze et al., 2011a; Lewis and Galloway, 2010; Devaux et al. 2011, 2015; Santos et al., 2013a,b). During previous studies, the methodological procedure of Comet assay was adapted and optimized for Palaemon sp spermatozoa and a reference data distribution was defined for the coastal species P. serratus (Erraud et al., 2018 a,b). The objective of this present work was to propose an alternative strategy to define a baseline for the native population of $P$. longirostris living in the Seine estuary, in order to assure a robust interpretation of this marker in this complex ecosystem. In invertebrate species, little information is available concerning DNA repair of spermatozoa and in a lesser extent in Palaemonidae spermatozoa in spite of their particularities, which differ from those of the aquatic invertebrates in both form and function (Braga et al. 2013). So, in the first step, different passive and active recovery approaches were performed on wild specimens (i.e. naturally exposed to Seine contamination) transferred to healthy conditions in laboratory to try to define the basal level of sperm DNA damage. In the second step, the sperm DNA integrity of the Seine estuary $P$. longirostris population was assessed during 6 sampling campaigns, in 2015, 2016 and 2017.

\section{Materials and methods}


Adult specimens of Palaemon longirostris (i.e. $32,4 \pm 3,6 \mathrm{~mm}$ of total body size) were collected along the salinity gradient in the mesohaline zone of the Seine estuary, between the Normandy and the Tancarville

124 Bridges, in April 2015, January 2016, May 2016, October 2016, April 2017 and October 2017 (Normandy,

125 France; Fig 1). Eight stations were monitored in each sampling campaign in order to find males, considering the 126 movement of the salinity gradient at the different seasons (Fig. 1): three stations in the vicinity of the Normandy 127 bridge (i.e. $\mathrm{NB} 1=$ Normandy bridge; NB2 = Grestain abbey; NB3 = Grestain); two stations at the mouth of the 128 Risle River (i.e. Ri1 = Berville-sur-mer ; Ri2 = Blanc banc); one station in the Risle River (i.e. RiR); two stations 129 at the proximity of the Tancarville bridge (i.e. TB1 = Pointe de la Roque; TB2 = Tancarville bridge).

130 The samplings were carried out by a fisherman provider (Prélèv’Mar®) using a prawn net dredged with a mesh 131 size of $11 \mathrm{~mm}$ and dredging at a depth of $7-9 \mathrm{~m}$. Water temperature, salinity and dissolved oxygen were 132 systematically recorded at each station during all samplings. Immediately after dredging, prawns were put in 13330 L-plastic containers supplied with the natural brackish water of the sampling station, under oxygenation until 134 the return to the laboratory (i.e. approximatively 3 hours). The presence of the appendix masculina (i.e. secondary sexual character) by an observation with binocular magnifier (8x) was used to select sexually mature male prawns and to separate them from females (Fig 2). Males were kept in plastic containers under oxygenation until analysis of sperm DNA damage, the next morning, as described in section 2.4.

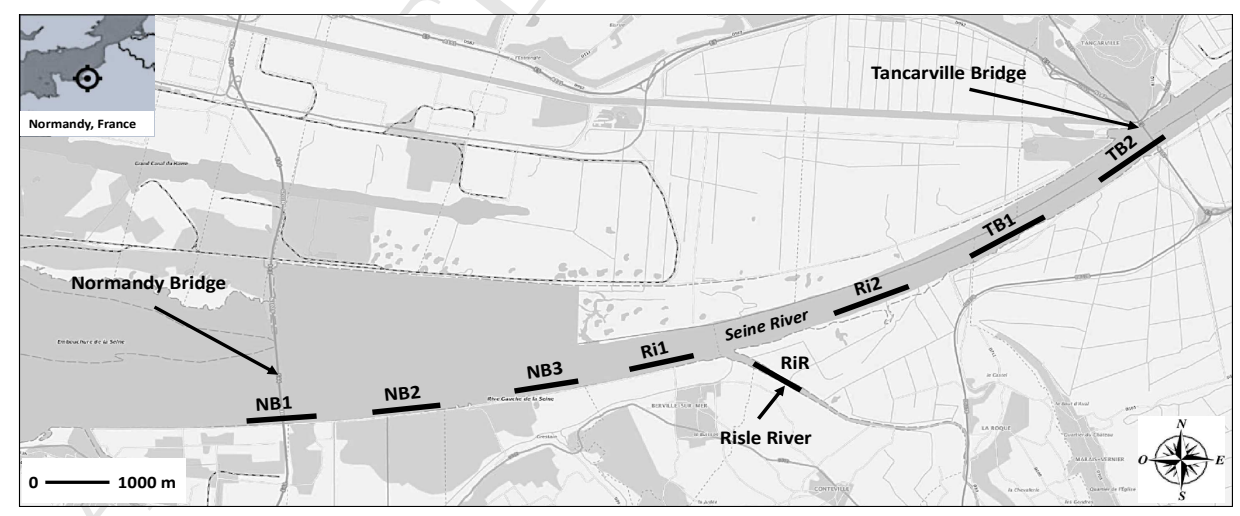

139 Figure 1. Localization of the sampling stations along the Seine estuary between the Normandy bridge and the 140 Tancarville bridge (Normandie; France). NB1 = Normandie bridge; NB2 = Grestain abbey; NB3 = Grestain; Ri1

$141=$ Berville sur mer; RiR = Risle River; Ri2 = Blanc banc; TB1 $=$ Pointe de la Roque and TB2 = Tancarville 142 bridge. 


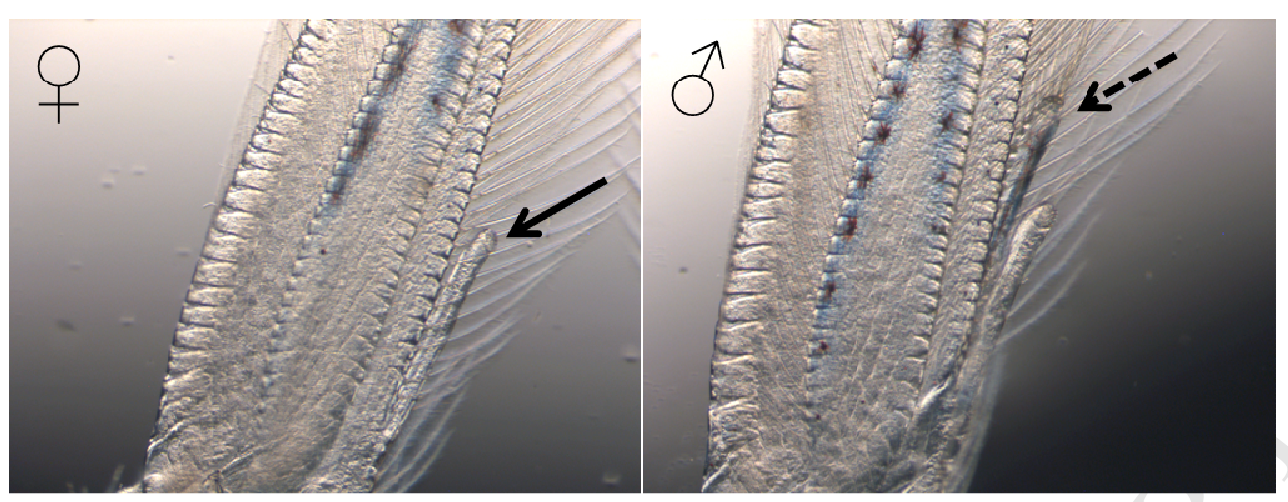

144 Figure 2. Binocular observation (8x) of the secondary sex characters, the appendix masculina, in

145 Palaemon longirostris at the second pleopode pair. The continuous arrow marks the appendix interna and the

146 hatched arrow marks the appendix masculina.

\section{2.2. Procedure of the sperm DNA damage analysis}

149 Spermatophores were extracted from the terminal ampullae before being transferred into $1.5 \mathrm{~mL}$-microtube filled 150 with $300 \mu \mathrm{L}$ of artificial brackish water (i.e. salinity of 15 ) adjusted to the hemolymphatic osmolality of 151 P. longirostris (i.e. $610-650 \mathrm{mOsmol} . \mathrm{kg}^{-1}$ ). Spermatophores were ripped by pipetting up and down until their 152 entire laceration. The mortality of spermatozoa suspension was assessed with the trypan blue test (i.e. $0.4 \% \mathrm{w} / \mathrm{v}$ ) 153 on KOVA $®$ slides, using a photonic microscope (400x). Only the samples displaying a sperm viability $\geq 85 \%$ 154 were used for the Comet assay. The procedure of the Comet assay was performed according to the methodology 155 developed by Singh et al. (1988) and previously adapted to Palaemonid prawns in Erraud et al. (2018a).

\subsection{Experiment of passive recovery in clean artificial sea water}

158 Sixty adult male prawns from the sampling of January 2016 were used for this experiment. To respond to the

159 experimental design, the specimens from sampling stations Ri1 and Ri2 were used because high densities of 160 prawns, displaying similar level of spermatozoa DNA damage (see section 3.1), were found on these stations 161 during this period. At the beginning, 20 prawns were sacrificed to assess the initial sperm DNA integrity (T0).

162 The other forty prawns were distributed in groups of 5 prawns per $2 \mathrm{~L}$-beaker containing $1 \mathrm{~L}$ of artificial 163 brackish-water (ABW) at salinity of $10, \mathrm{pH} 7.7 \pm 0.2$, and $12.0 \pm 0.3{ }^{\circ} \mathrm{C}$ (i.e. approximating conditions found at 164 the sampling stations at this period) and kept in these conditions during 20 days. ABW was obtained by dissolution of TETRA®Sea salt (i.e. salt used for marine aquarium maintenance) at a concentration of 12.3 g.L $\mathrm{L}^{-1}$ 
(i.e. salinity of 10). Mortality was followed every day of this experiment. Every beaker was provided with additional aeration to maintain optimum conditions, and the water was monitored daily for nitrite $\left(\mathrm{NO}_{2}{ }^{-}\right)$and nitrate $\left(\mathrm{NO}_{3}{ }^{-}\right)$concentrations which were always included in low values (i.e. between 0.01 to $0.02 \mathrm{mg} . \mathrm{L}^{-1}$ for nitrite and 5 to $9 \mathrm{mg} \cdot \mathrm{L}^{-1}$ of nitrate). The brackish water was renewed every 72 hours. Prawns were fed daily ad libitum with pellet B-Penaeus Grower RCE 1 (Le Gouessant ${ }^{\circledR}$ ) according to manufacturer’s recommendations during the experiment period. Batches of 4 beakers were stopped after 10 and 20 days of recovery (i.e. T10 and T20). Sperm samples from each surviving prawn were obtained and individually analysed as described in section

173 2.4. The DNA integrity was measured only for the sperm samples displaying a cell viability $\geq 85 \%$ (i.e. $n=17$,

17412 and 14 for T0, T10 and T20, respectively).

\subsection{Experiment of active recovery by three successive forced spermatophore extraction / reformation}

177 To ensure that the spermatophore turnover occurs with sperm showing a lower history of exposure, this experiment was conducted during the sexual latency. Seventy adult male prawns of the October 2016 sampling pooled from stations Ri1 and Ri2 were used for the same reasons than for the passive recovery (see section 2.2). Spermatophores for each male prawn were immediately extracted and the 20 sperm suspensions were randomly selected to obtain the T0. Just after the spermatophore extraction, prawns were distributed by 5 prawns per $2 \mathrm{~L}-$ beaker supplied with $1 \mathrm{~L}$ of $\mathrm{ABW}$ at salinity of $5, \mathrm{pH} 7.9$ and $13^{\circ} \mathrm{C}$ (i.e. approximating conditions found at the sampling stations at this period) and maintained for 30 days. ABW was obtained by dissolution of TETRA®Sea salt at a concentration of 6.1 g.L $\mathrm{L}^{-1}$ (i.e. salinity of 5). Fifteen days between each spermatophore extraction were necessary at this season to allow the formation of a new spermatophore in the terminal ampullae. The mortality of prawns was monitored every day. The maintenance of prawns was performed similar to that detailed in section 2.2. After 15 days and 30 days (i.e. T15 and T30), new extractions of spermatophores were performed on all prawns. Twenty sperm suspensions were randomly selected for DNA integrity analysis. The sperm samples of each prawn were obtained and individually analysed as described in section 2.4. The DNA integrity was measured only for the sperm samples displaying a cell survival rate $\geq 85 \%$ (i.e. $n=17,17$ and 12 for $\mathrm{T} 0, \mathrm{~T} 15$ 191 and T30, respectively).

\subsection{Statistical analysis}

194 Statistical analyses were performed with the R studio software v0.99.903 (RStudio Inc.). All results are 
expressed as mean \pm standard deviation of all sperm suspensions for each condition. As normality and homoscedasticity was not respected for our comet assay data, only non-parametric tests were used. For DNA damage values of passive and active recovery, statistical comparisons of recovery times were assessed using the non-parametric Kruskal-Wallis rank ANOVA test, followed when significant by Wilcoxon rank sum test to identify groups that differed significantly from the control. The statistical significance level was set at 0.05 . A maximum reference threshold (unilateral $95^{\text {th }}$ percentile) of DNA damage was defined by the basis of data measured after active recovery (i.e. T15 and T30; $\mathrm{n}=29$; see section 3.2).

For each sampling campaign and each station, a pairwise comparison using a non-parametric Nemenyi rank sum test was used to assess the deviation of sperm DNA integrity from the defined baseline. A second non-parametric test, the Scheirer-Ray-Hare pairwise test, was used to assess the effects between stations and seasons.

\section{Results}

\subsection{Kinetics of DNA damage in spermatozoa of prawns from the Seine River during passive recovery}

208 During this experiment, the prawn survival were 60 and $95 \%$ in the batches of prawns stopped after 10 and 20 209 days, respectively. The death was the result of cannibalism after moulting during the previous night. A slight but 210 significant decrease of the sperm viability was observed after the first 10 days of this passive recovery 211 (Wilkoxon rank sum test; $p=0.0004307$ ), but was not extended during the last 10 days (Wilkoxon rank sum 212 test; $p=0.2605$ ) with a viability at T0, T10 and T20 of $95.9 \pm 3.9,90.3 \pm 3.8$ and $93.3 \pm 6.4 \%$, respectively.

213 Fig. 3 shows the level of DNA damage measured in spermatozoa of the prawns sampled in the Seine estuary in 214 January 2016 (i.e. T0; $n=17$ prawns) and after 10 and 20 days of passive recovery in clean ABW ( $n=12$ and 14 215 prawns, respectively). No significant decrease in the mean level of DNA damage was observed between T0, T10 216 and T20 with levels reaching $110.5 \pm 11.3,112.3 \pm 10.7$ and $106.1 \pm 22.7$ A.U. (i.e. Arbitrary Unit), respectively 217 (Kruskal-Wallis rank test, $p=0.397$ ). However, it can be noted that an increase of the inter-individual variability 218 at $\mathrm{T} 20$ days (i.e. Variation Coefficient $\mathrm{VC}=21.3 \%$ ) was observed compared to the T0 and T10 days (i.e. 10.3 219 and $9.6 \%$, respectively). 


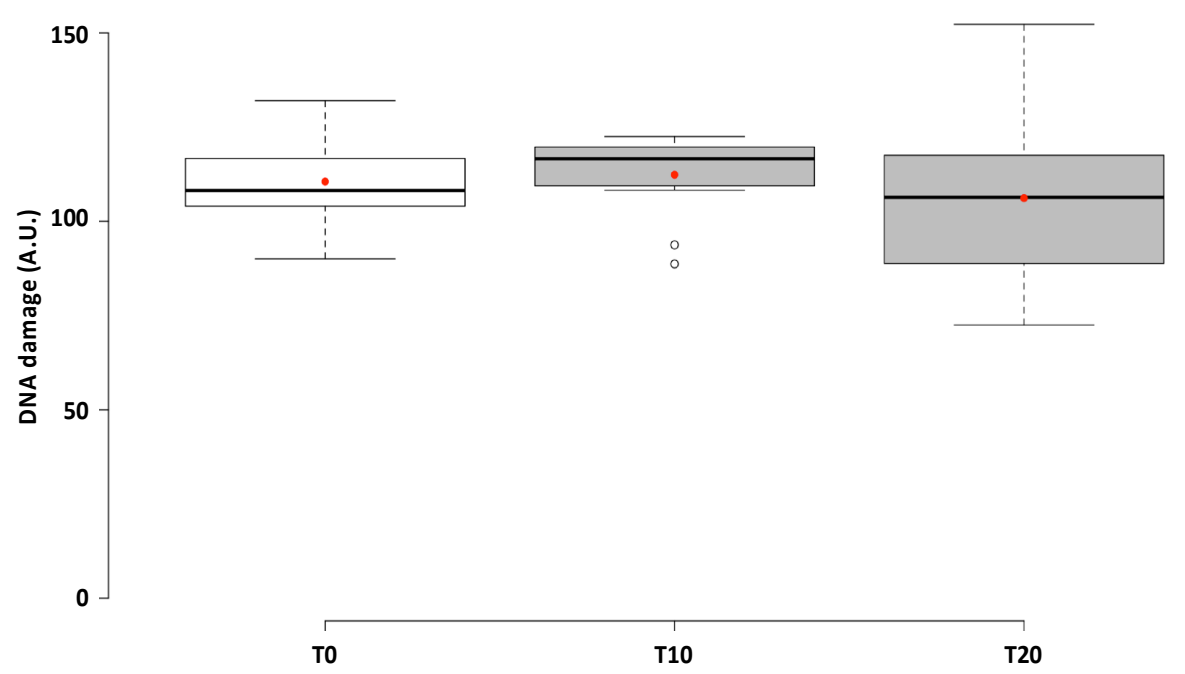

221 Figure 3. Sperm DNA damage measured using Comet assay in Palaemon longirostris specimens sampled in Seine estuary, just before (i.e. T0; $n=17$ ) and after 10 and 20 days in laboratory recovery period in healthy environment (T10 and T20; $n=12$ and 14). Results are shown in boxplot (i.e. the median, the first and the third quartiles, the non-outliers range and the outliers), with the mean (red point).

\subsection{Definition of reference values of DNA damage in spermatozoa of prawns in laboratory experiment}

During this experiment, 21 prawns died which represent $30 \%$ of the total number of prawns. Extraction of spermatophores was the major source of mortality in this experiment with 7 and 8 dead prawns after the first and second extractions, respectively. The 6 other dead prawns occurred after the moult as a result of cannibalism. A slight but significant decrease of the cells viability was observed between T10 and T30 with viability at T0, T15 and T30 reaching $97.0 \pm 2.0,94.8 \pm 5.3$ and $92.2 \pm 6.6 \%$, respectively (Wilcoxon rank sum test; $p=0.002366$ ).

232 Fig. 4 presents the level of DNA damage measured in spermatozoa of prawns before (i.e. T0) and after the first 233 and second forced spermatophore extractions / reformations during a recovery phase in clean ABW (i.e. T15 and 234 T30). At T0, the mean level of DNA damage in spermatozoa of prawns has attained $97.5 \pm 7.4$ A.U. After the 235 first reformation, at T15, a significant decrease of $54.8 \%$ in the mean level of DNA damage was observed 236 reaching $53.4 \pm 8.9$ A.U. (Wilcoxon rank sum test; $p<0.001$ ). In contrast, after the third extraction, a 237 stabilization of the mean level of DNA damage was observed between the first and the second reformation (i.e. $23857.0 \pm 9.1 \mathrm{AU}$ ) (Wilcoxon rank sum test; $p=0.3033$ ). Hence, on the basis of the data $\mathrm{T} 15$ and T30 (i.e. $\mathrm{n}=17$ 239 and 12, respectively), a baseline level was established, with a mean value of $54.9 \pm 9.1$ A.U. and a more than $24095 \%$ unilateral confidence threshold of 69.7 A.U. This maximum damage threshold is based on the variation of 
241 the 29 prawns' level of DNA damage at T15 and T30 days (i.e. $n=17$ and $n=12$, respectively), which notably

242 presented a quite small inter-individual variability (Variation Coefficient - VC = 16.4\%).

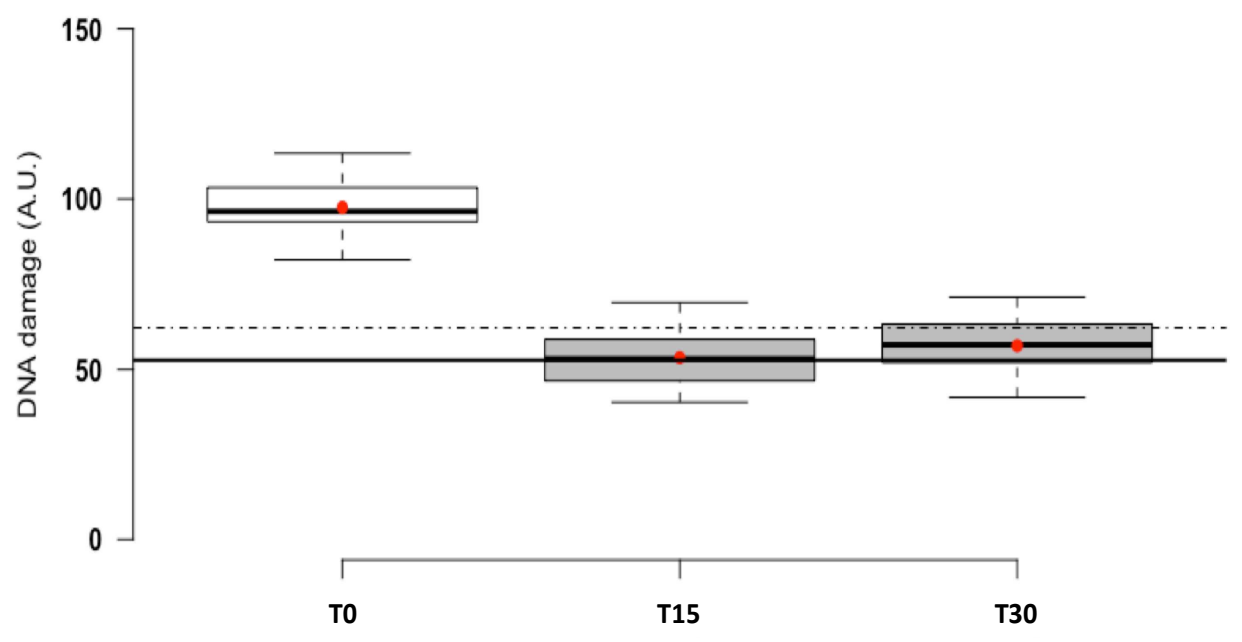

244 Figure 4. Sperm DNA damage measured using Comet assay in Palaemon longirostris specimens sampled in

245 Seine estuary after 3 successive extractions of spermatophores performed just before (i.e. T0; $n=17)$ and after

24615 and 30 days of recovery under laboratory conditions in healthy medium (T15 and T30; $\mathrm{n}=17$ and 12).

247 Results are shown in boxplot (i.e. the median, the first and the third quartiles, the non-outliers range and the

248 outliers), with the mean (red point). Continuous line represents the mean of DNA damage values recorded at T15

249 and T30 and the dashed line represents the unilateral $95 \%$ confidence interval.

252 The seasonal variations of water temperature (i.e. from 5.7 to $14.8{ }^{\circ} \mathrm{C}$ ), salinity (i.e. salinity from 3 to 16 ) and 253 dissolved oxygen (i.e. $5.1-8.6 \mathrm{ppm}$ ) observed at the sampling area during the different campaigns are 254 represented in Table 1. Fig. 5 presents the level of sperm DNA damage measured in native population of prawns 255 sampled at a maximum of seven stations located between the Normandy and the Tancarville bridges. 


\section{ACCEPTED MANUSCRIPT}

261 Table 1. Detailed informations concerning the different campaigns of sampling on the 8 stations from 2015 to

2017. $\mathrm{ND}=$ not determined.

\begin{tabular}{|c|c|c|c|c|c|}
\hline Sampling dates & Sites & $\mathrm{T}^{\circ} \mathrm{C}$ & Salinity & Dissolved oxygen (ppm) & Dissolved oxygen (\%) \\
\hline \multirow{8}{*}{$16 / 04 / 2015$} & NB1 & 12.7 & 14 & ND & ND \\
\hline & NB2 & 12.5 & 16 & ND & $\mathrm{ND}$ \\
\hline & NB3 & 12.6 & 12 & ND & ND \\
\hline & Ri1 & 12.7 & 10 & ND & ND \\
\hline & RiR & ND & ND & ND & ND \\
\hline & $\mathrm{Ri} 2$ & 12.9 & 8 & ND & ND \\
\hline & TB1 & 13.1 & 6 & ND & $\mathrm{ND}$ \\
\hline & TB2 & 13.3 & 3 & ND & ND \\
\hline \multirow{8}{*}{$21 / 01 / 2016$} & NB1 & 5.7 & 17 & ND & ND \\
\hline & NB2 & 5.7 & 15 & ND & ND \\
\hline & NB3 & 5.7 & 12 & ND & ND \\
\hline & Ri1 & 5.8 & 9 & ND & ND \\
\hline & RiR & 5.9 & 10 & ND & ND \\
\hline & $\mathrm{Ri} 2$ & 5.7 & 8 & ND & ND \\
\hline & TB1 & 5.8 & 8 & ND & ND \\
\hline & TB2 & 5.8 & 7 & ND & ND \\
\hline \multirow{8}{*}{$13 / 05 / 2016$} & NB1 & 14.3 & 11 & 5.88 & 82.3 \\
\hline & NB2 & 14.8 & 9 & 6.46 & 80.4 \\
\hline & NB3 & 14.7 & 7 & 5.27 & 79.6 \\
\hline & Ri1 & 14.1 & 6 & 5.17 & 76.5 \\
\hline & RiR & 14.5 & 5 & 5.93 & 81.4 \\
\hline & $\mathrm{Ri} 2$ & 14.3 & 5 & 5.15 & 78.3 \\
\hline & TB1 & 14.1 & 4 & 6.2 & 79.0 \\
\hline & TB2 & 14.7 & 3 & 5.61 & 80.0 \\
\hline \multirow{8}{*}{$25 / 10 / 2016$} & NB1 & 13.7 & 25 & 7.21 & 81.4 \\
\hline & NB2 & 13.1 & 19 & 7.52 & 83.6 \\
\hline & NB3 & 12.8 & 16 & 7.34 & 82.5 \\
\hline & Ri1 & 12.9 & 14 & 7.63 & 86.8 \\
\hline & RiR & 12.7 & 5 & 8.02 & 90.2 \\
\hline & $\mathrm{Ri} 2$ & 12.9 & 6 & 7.83 & 87.4 \\
\hline & TB1 & 13.0 & 5 & 7.65 & 85.9 \\
\hline & TB2 & 12.9 & 4 & 7.47 & 81.7 \\
\hline \multirow{8}{*}{$17 / 04 / 2017$} & NB1 & 12.5 & 14 & 8.60 & 92.0 \\
\hline & NB2 & 12.5 & 13 & 8.70 & 95.8 \\
\hline & NB3 & 12.4 & 12 & 8.20 & 90.6 \\
\hline & Ri1 & 12.5 & 10 & 8.17 & 90.1 \\
\hline & RiR & 13.2 & 4 & 8.58 & 92.0 \\
\hline & $\mathrm{Ri} 2$ & 12.9 & 6 & 7.83 & 88.0 \\
\hline & TB1 & 13.1 & 3 & 8.02 & 90.0 \\
\hline & TB2 & 13.1 & 3 & 7.99 & 88.0 \\
\hline \multirow{8}{*}{$25 / 10 / 2017$} & NB1 & 14 & 19 & 6.95 & 85.3 \\
\hline & NB2 & 13.9 & 17 & 7.58 & 83.1 \\
\hline & NB3 & 13.7 & 16 & 7.21 & 83.2 \\
\hline & Ri1 & 13.6 & 15 & 7.64 & 84.4 \\
\hline & $\mathrm{RiR}$ & 14.3 & 6 & 8.01 & 89.5 \\
\hline & $\mathrm{Ri} 2$ & 14 & 7 & 7.73 & 87.2 \\
\hline & TB1 & 14.2 & 10 & 7.54 & 82.2 \\
\hline & TB2 & 14.3 & 6 & 7.61 & 83.9 \\
\hline
\end{tabular}




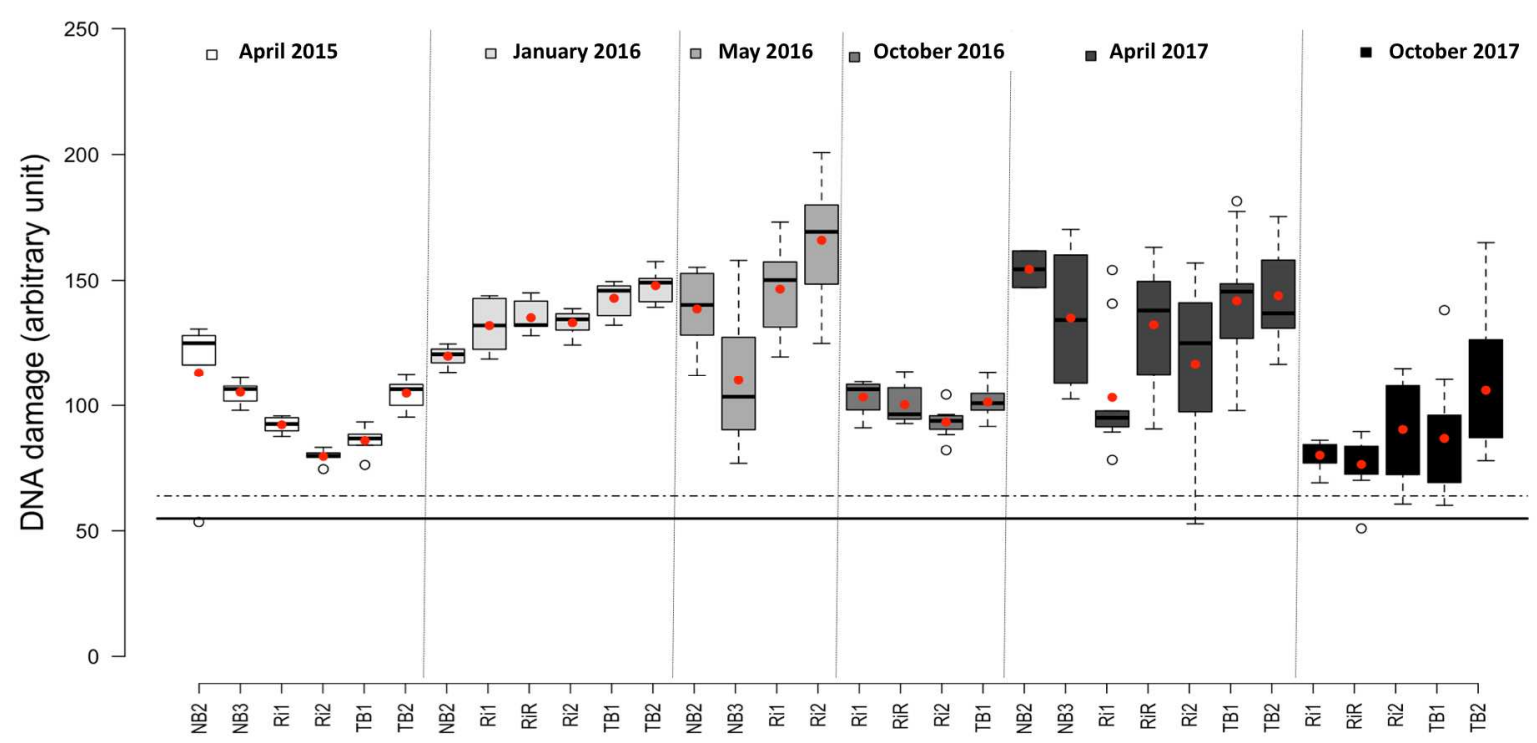

Figure 5. Sperm DNA damage measured using Comet assay in Palaemon longirostris specimens sampled in a maximum of 7 stations along the mesohaline part of the Seine estuary during 6 campaigns in 2015, 2016 and 2017. Results are shown in boxplot (i.e. the median, the first and the third quartiles, the non-outliers range and the outliers), with the mean (red point). $n=10$ specimens per station.

Prawns sampled in all stations and campaigns presented mean DNA damage levels above the maximum damage threshold of 69.7 A.U. defined in the previous laboratory experiment (see section 3.2). Considering the mean level of all stations for each sampling campaign, the lowest levels of sperm DNA damage were observed in April 2015, October 2016 and October 2017 with values reaching $96.8 \pm 16.8,99.0 \pm 7.7$ and $88.7 \pm 21.7$ A.U. (i.e. 38.9, 42.1 and $27.3 \%$ above the maximum threshold), respectively. Contrarily, the highest levels of sperm DNA damage were observed in January 2016, May 2016 and April 2017 displaying levels of $135.2 \pm 11.1,137.4 \pm$ 28.2 and $129.3 \pm 21.7$ A.U, (i.e. $94.0,97.1$ and $85.5 \%$ above the threshold value), respectively. Considering now 278 the inter-site variability of each sampling campaign, during the spring (i.e. April 2015, May 2016 and April 2017), it can be underlined that the prawns showed an inter-site variability with a higher mean level of DNA damage at each sampling station extremity considering the location of prawns (Nemenyi rank sum test, $p<$ 281 0.05). Indeed, the lowest levels of DNA damage were observed in the middle of the studied area, Stations Ri2, 282 NB3 and Ri1 displaying a minimum of $79.6 \pm 3.2,110.1 \pm 27.2$ and 103.2 \pm 24.2 A.U. in April 2015, May 2016, 283 April 2017, respectively. Conversely, during the sampling of January 2016 and October 2016 no significant 284 difference was observed between stations (Nemenyi rank sum test, $p>0.05$ ). Moreover, during May 2016, April 2852017 and October 2017, a significant inter-individual variability at all stations has been observed (i.e. Variation 
Coefficient $\%$ from 10.9 to $24.7 \%$, from 6.7 to $29.8 \%$ and from 7.6 to $27.2 \%$, respectively) which is not the case in April 2015, January 2016 and October 2016 (i.e. VC \% from 3.2 to $7.5 \%$, from 3.5 to $8.4 \%$ and from 6.4 to $8.1 \%$, respectively). In fine, a significant variability on the level of sperm DNA damage between-month was observed (Scheirer-Ray-Hare pairwise test; $p=2.220446 \mathrm{e}-16)$.

\section{Discussion}

In this present study, the ability of Palaemon longirostris spermatozoa to recover sperm DNA damage was assessed from indigenous specimens of the Seine estuary (i.e. naturally exposed to environmental contamination) after transfer in the laboratory conditions, during a 20 days-period. In the case of the majority of spermatozoa, they are known to be devoid of DNA repair mechanisms (Aitken et al., 2004). However, crustaceans spermatozoa, and more precisely Palaemonidae prawns, present a number of morphological and structural particularities (e.g. afflagelate, no systematic presence of an acrosome, and mainly a totally decondensed chromatin; Braga et al., 2013), compared with the other ent-aqua sperm, which seems closer of somatic cells. Prawns sampled in the Seine estuary (i.e. T0) displayed high sperm DNA damage levels compared to the baseline recently described in the coastal species Palaemon serratus from a reference station of the Seine Bay (i.e. Yport; 52.6 \pm 5.6 A.U. with the upper 95\% unilateral confidence threshold at 61.7 A.U; Erraud et al., 2018). After 10 and 20 days of passive recovery in P. longirostris, the level of DNA damage was persistent over time (i.e. $112.3 \pm 10.7$ and $106.1 \pm 22.7$ A.U, respectively). This strategy to reach the baseline level of DNA damage for its use in biomonitoring program seems not to be operational. This result suggested a lack of DNA repair mechanisms in Palaemon sp spermatozoa and is coherent with previous reports in another crustacean group. Indeed, Lacaze et al. (2011b) observed no DNA repair in the sperm of the freshwater Gammarus fossarum after an initial exposure to the model genotoxicant methyl methane sulfonate for 5 days, and 4 days of recovery in clean water. The lack of recovery of the sperm DNA damage in P. longirostris reinforces its relevance in the environmental survey. Indeed, to be useful in this field, a biomarker has to be representative from stress over

311 time (Wu et al. 2005). In this way, the capability of a fast recovering biomarker represents a real disadvantage

312 for monitoring applications by reflecting only a recent pollution episode and not providing the time integration 313 of contamination effects (Sanchez et al., 2008; Webb and Gagnon, 2013). Without repair mechanisms, the DNA 314 integrity will depend on the cells sensitivity, genotoxic pressure and time of exposure. Although spermatogenesis 
in the majority of crustaceans is performed within the testis, many later stages of this process are completed upon entering the testicular lumen and the proximal part of the vas deferens to assume complete morphological sperm characteristics (Subramoniam, 2016). Starting from this statement, an exposure of the spermatic line cells within the testicular lumen or the vas deferens could still display DNA repair mechanisms and consequently show less significant DNA damage than spermatozoa exposed in the spermatophore. Lacaze et al. (2011a) demonstrated that the sensitivity of Gammarid sperm DNA integrity could depend on the spermatogenesis stage. The authors observed the highest level of DNA damage in spermatozoa collected in sexual mature males in comparison to spermatozoa from males in the early stage of spermatogenesis. To ensure the renewal of the mature spermatozoa stock which would be unexposed, we forced the formation of new spermatophores by a manual extraction during the sexual rest period (i.e. with the vas deferens empty). In the present work, we defined that 15 days was necessary for $P$. longirostris to renew a spermatophore after a forced extraction. This methodology was already used in three Peneidae species in aquaculture to assess the time necessary for the renewal of spermatophores after a manual extraction and after a natural mating session (Leung-trujillo and Lawrence, 1991). In these tropical species, a range from two days to seven days was necessary depended on the species. The time of renewal in $P$. longirostris was longer than for Peneidae prawns; this does not seem surprising since the metabolism is slowed down in temperate species. After the first renewal of spermatophores (i.e. T15), the level of DNA damage decreases sharply to attain a relatively low level. Ultimately, a settling down of the sperm level of DNA damage was observed after the second reformation (i.e. T30). A mean value of $54.9 \pm 9.1$ A.U. and a

333 maximum threshold corresponding to the unilateral $95 \%$ confidence intervals of 69.7 A.U was generated on the basis of the compilation of the levels of DNA damage recorded at T15 and T30 days ( $n=17$ and 12 prawns, respectively). This level of DNA damage seems coherent with the reference distribution defined in a previous study (based on a monthly chronological data set of two years at a reference station) in the coastal species Palaemon serratus (i.e. a mean \pm SD of 52.6 \pm 5.6 A.U. and a IC 95\% of 61.7 A.U.; Erraud et al. 2018). Despite its apparent limitation in terms of replication of conditions between the laboratory and field conditions (i.e. water

339 chemistry, circadian cycles and food), the results of this experiment seem to be coherent with those obtained in realistic conditions in the coastal species for which no effect of confounding factors (i.e. season, temperature,

341 age and moult-stage) was observed. This observation improves the relevance of the procedure for an active recovery to reach a baseline level of sperm DNA integrity in Palaemonidae prawns. Consequently, a DNA

343 damage level above the threshold could be interpreted as a modulation, resulting from an exposure to 344 contaminants. 
347 The levels of sperm DNA damage were measured in prawns coming from a maximum of 7 different stations 348 along the salinity gradient of the Seine estuary, during April 2015, January 2016, May 2016, October 2016, April 3492017 and October 2017. All investigated stations during the 6 sampling campaigns exhibited high levels of 350 sperm DNA damage with percentages of induction above the maximum threshold (previously described in 351 section $3.2 \& 4.1$ ) ranging from $27.3 \%$ in autumn 2017 (i.e. October) to $97.1 \%$ in spring 2017 (i.e. April), 352 highlighting the abnormally elevated response of this biomarker in this part of the Seine estuary. If we compare 353 these results with the ones obtained on the coastal species P. serratus in different stations of the Seine Bay in 354 autumn 2015 and 2016 (i.e. October), in most cases the percentage of induction is higher in the Seine estuary 355 than in the three most impacted stations of the Seine Bay located at the north of the mouth of the river (i.e. 16.3 356 to $29.5 \%$ ) (Erraud et al. 2018). This observation is in accordance with the geographical gradient of 357 contamination which is diluted from the estuary to the coastline water bodies.

358 It may be expected in the estuary biotope, which displays considerable physico-chemical fluctuations, that 359 environmental conditions could impact the basal level of a biological response, confusing biomarker 360 interpretation. The influence of environmental factors is generally studied in reference station (i.e. 361 uncontaminated) or in controlled laboratory condition (i.e. in a lesser environmentally realism) to avoid all 362 agonistic or antagonistic effects of pollution during the interpretation (e.g. Xuereb et al., 2009; Lacaze et al., 363 2011a; Coulaud 2011). In this work, the correlations between temperature, dissolved oxygen or salinity, and 364 DNA damage were tested, and no significant effect was observed (data not shown). However, regarding the high 365 level of DNA damage observed during this study and the degraded chemical quality of the Seine estuary, it 366 seemed no relevant to use this data to validate the absence of physical factor influence. Nevertheless, the return 367 on previous experiment in the coastal species Palaemon serratus added to the observations reported in the 368 literature lead us to exclude incidence of these confounding factors in the range of variations observed in the 369 present study. Indeed, precedent works have shown that the range of temperature measured in the living 370 environment of prawns seems to have no influence on the baseline of sperm DNA damage for crustaceans, as in 371 the common prawn P. serratus (Erraud et al., 2018b) or the freshwater gammarid G. fossarum (Lacaze et al., 372 2011b). In regard to the salinity or dissolved oxygen level, to our knowledge, no information exists concerning 373 the influence of these two abiotic factors on the baseline of sperm DNA damage. However, Sing and Harlt 
374 (2012), facilitated by assessing the impact of confounding factors in estuarine ecosystems, demonstrated in

375 laboratory experiments that salinity from 8 to 32 was not a confounding factor for DNA integrity in gill cells and

376 haemocytes in M. edulis. Moreover, P. longirostris is considered as an hyper euryhaline species which allow to conserve a great homeostasis condition facing salinity's variations (Campbell \& Jones, 1989). So, it is difficult to

378 believe that salinity can have an effect on sperm DNA damage levels in the range of salinity observed during the present study. Concerning the level of dissolved oxygen, an example of induced DNA strand breaks has already been shown in gill cells of the rainbow trout Oncorhyncus mykiss (Liepelt et al. 1995) and the common carp Cyprinus carpio (Mustafa et al. 2011), but only at the hypoxia stage (i.e. $<3 \mathrm{mg} . \mathrm{L}^{-1}$ ). During our different sampling campaigns, the lowest concentration of dissolved oxygen was observed during the spring 2016 (i.e. May 2016) with values ranging from 5.2 to $6.5 \mathrm{mg} . \mathrm{L}^{-1}$ which are not considered to be low values. These punctual measurements are corroborated by dissolved oxygen data collected by the SYNAPSE network (i.e. continuous monitoring of physiochemical parameters in the Seine River) which underlined the lack of anoxic episodes throughout the years of study (i.e. values upper than $5 \mathrm{mg} . \mathrm{L}^{-1}$ ) (Romero et al., 2016).

Different patterns of sperm DNA damage were observed according to the season. In the current state of knowledge relative to the ecophysiology of $P$. longirostris and to the hydro-sedimentology and contamination of the Seine estuary (i.e. data generated at larger spatial and temporal frequencies), the fine interpretation of these patterns remains somewhat speculative. For example, the highest levels of DNA integrity of P. longirostris spermatozoa were observed during January 2016, May 2016 and April 2017. These observations could be explained by the high-water level period (i.e. from December to April) and consequently by the contamination loading from the river effluents and leaching of flood soils. In contrast, in October 2016 and October 2017, the

394 level of the DNA integrity was lower, which could be in relation with the low-water level in accordance with the upwelling of coastal water in the investigated area. In other way, in January and October 2016, the levels of damage recorded in the different stations were close, displaying a low inter-individual variation coefficient (i.e. from 7 to $8 \%$ ). Conversely, notable inter-station variabilities were observed during the spring campaigns (i.e.

398 April 2015, May 2016 and April 2017); the highest levels of DNA damage were measured at both extremities of the sampling area. It can be hypothesized that these fluctuations could be the result of local chemical pressure or an effect of the breeding period of the white prawn. It was shown in Palaemonidae species (Macrobrachium nobili and Macrobrachium rosenbergi), that during this period a single male could ensure the fertilization of several females in a row (Balasundaram \& Pandian, 1982; Ling, 1967). So, it could be hypothesized that the sexual activity of male specimens accentuates the turnover of sperm stock, acting as an active recovery. The 
lowest level of DNA observed in the middle part of the area could be explained by a more intense sexual activity (Aurousseau, 1984). In the same way, the more pronounced inter-individual variability could be the result of the temporality of reproduction events that could differ between specimens.

407 Further research must be performed to gain a better understanding of these spatial and temporal variations on the 408 toxicological response and lead to a survey protocol which is as relevant as possible. Anyway, in the current situation, the global work conducted on the genus Palaemon sp., allowed to quantify a genotoxic pressure within a transition waterbody regarding a robust reference value, which constitute an important challenge for the application and the interpretation of biomarkers in fluctuating systems as estuaries.

414 The use of passive recovery in controlled laboratory conditions showed the lack of DNA repair mechanisms in 415 Palaemon sperm, underlining the ability of the sperm DNA damage measurement for integrating the history of 416 exposure to toxicological stress. Conversely, the active recovery (in the same conditions) appeared to be a 417 relevant alternative strategy to define a baseline for this biomarker in an estuarine palaemonid prawn. This 418 baseline of Palaemon longirostris was perfectly in accordance with the reference distribution defined in the 419 coastal species Palaemon serratus suggesting the possibility of using an inter-species reference distribution to 420 invest the continuum estuary/littoral of the Seine Bay. Although this study was a preliminary step, the use of this 421 baseline demonstrated the abnormal level of sperm DNA damage within the autochthonous $P$. longirostris 422 population of the Seine estuary during six campaigns from 2015 to 2017. However, further studies could be done 423 to give more precision to the environmental diagnosis. For example, deployment of an active biomonitoring 424 approach based on the transplantation of prawns into caging systems coupled to physico-chemical data loggers 425 and chemical integrative samplers could lead to a better control of the in situ exposure conditions and 426 consequently to a more accurate understanding of the biomarker fluctuations.

\section{Acknowledgment}

429 This study was supported by the project ECOTONES funded by the program Seine-Aval V (Public Interest 430 Groups Seine-Aval) (SA5 QO 2014), the Research Federation CNRS 3730 SCALE and the Normandy Region. 431 The authors also thank Mrs. D. Hallidy for proof- reading the English. 
Aurousseau, J. M., 1984. Éléments d'écologie de la crevette blanche, Palaemon longirostris, dans l'estuaire de la Gironde. Dynamique de la population et production (Doctoral dissertation, Thèse de doctorat, Biologie Animale mention Écologie, University of Paris VI, Paris, France).

Aitken, R.J., Koopman, P., Lewis, S.E.M., 2004. Seeds of concern. Nat. news 432, 48-52.

Anderson, G., 1985. Species Profiles. Life Histories and Environmental Requirements of Coastal Fishes and Invertebrates (Gulf of Mexico). Grass Shrimp. US Fish Wild Serv. Biol. Rep. 82, 11-35.

Balasundaram, C., \& Pandian, T. J., 1982. Egg loss during incubation in Macrobrachium nobilii (Henderson \& Mathai). J. Exp. Mar. Biol. Ecol., 59(2-3), 289-299.

Barjhoux, I., Baudrimont, M., Morin, B., Landi, L., Gonzalez, P., Cachot, J., 2012. Effects of copper and cadmium spiked-sediments on embryonic development of Japanese medaka (Oryzias latipes). Ecotoxicol. Environ. Saf. 79, 272-282.

Barrick, A., Châtel, A., Marion, J.M., Perrein-Ettajani, H., Bruneau, M., Mouneyrac, C., 2016. A novel methodology for the determination of biomarker baseline levels in the marine polychaete Hediste diversicolor. Mar. Pollut. Bull. 108, 275-280.

Bocquene, G., Bellanger, C., Cadiou, Y., Galgani, F., 1995. Joint action of combinations of pollutants on the acetylcholinesterase activity of several marine species. Ecotoxicology 4, 266-279.

Béguer, M., Bergé, J., Girardin, M., \& Boët, P., 2010. Reproductive biology of Palaemon longirostris (Decapoda: Palaemonidae) from Gironde estuary (France), with a comparison with other European populations. J. Crustacean Biol., 30(2), 175-185.

Braga, A., Nakayama, C.L., Poersch, L., Wasielesky, W., 2013. Unistellate spermatozoa of decapods: Comparative evaluation and evolution of the morphology. Zoomorphology 132, 261-284.

Burgeot, T., Akcha, F., Ménard, D., Robinson, C., Loizeau, V., Brach-Papa, C., Martínez-Gòmez, C., Le Goff, J., Budzinski, H., Le Menach, K., Cachot, J., Minier, C., Broeg, K., Hylland, K., 2017. Integrated monitoring of chemicals and their effects on four sentinel species, Limanda limanda, Platichthys flesus, Nucella lapillus and Mytilus sp., in Seine Bay: A key step towards applying biological effects to 
monitoring. Mar. Environ. Res. 124, 92-105.

460

461

462

463

464

465

466

467

468

469

470

471

472

473

474

475

476

477

478

479

480

481

482

Cachot, J., Geffard, O., Augagneur, S., Lacroix, S., Le Menach, K., Peluhet, L., Couteau, J., Denier, X., Devier, M.H., Pottier, D., Budzinski, H., 2006. Evidence of genotoxicity related to high PAH content of sediments in the upper part of the Seine estuary (Normandy, France). Aquat. Toxicol. 79, 257-267.

Cailleaud, K., Forget-Leray, J., Souissi, S., Hilde, D., LeMenach, K., Budzinski, H., 2007a. Seasonal variation of hydrophobic organic contaminant concentrations in the water-column of the Seine estuary and their transfer to a planktonic species Eurytemora affinis (Calanoïd, copepod). Part 1: Alkylphenolpolyethoxylates. Chemosphere 70, 270-280.

Cailleaud, K., Forget-Leray, J., Souissi, S., Lardy, S., Augagneur, S., Budzinski, H., 2007b. Seasonal variation of hydrophobic organic contaminant concentrations in the water-column of the Seine Estuary and their transfer to a planktonic species Eurytemora affinis (Calanoïd, copepod). Part 2: Alkylphenolpolyethoxylates. Chemosphere 70, 281-287.

Campbell, P.J., Jones, M.B., 1989. Adaptations of the prawn Palaemon longirostris (Crustacea, Decapoda) to life in dilute saline regions of estuaries: Effect of body size, temperature and season on salinity tolerance. Mar. Biol. 53, 685-689.

Campillo, A., 1975. Contribution à l'étude de l'élevage de la crevette rose Palaemon serratus (Pennant) en captivité. Rev. Trav. Inst. Pêches marit. 39, 381-393.

Carpentier, S., Moilleron, R., Beltran, C., Hervé, D., Thévenot, D., 2002. Quality of dredged material in the River Seine basin (France). I. Physico-chemical properties. Sci. Total Environ. 295, 101-113.

Chapman, P. M., Wang, F., 2001. Assessing sediment contamination in estuaries. Environ. Toxicol. Chem., $20(1), 3-22$.

Claxton, L.D., Houk, V.S., Hughes, T.J., 1998. Genetoxicity of industrial wastes and effluents. Mutat. Res. 410, $237-243$.

Coulaud, R., Geffard, O., Xuereb, B., Lacaze, E., Quéau, H., Garric, J., Charles, S., Chaumot, A., 2011. In situ feeding assay with Gammarus fossarum (Crustacea): Modelling the influence of confounding factors to improve water quality biomonitoring. Water Res. 45, 6417-6429.

Devaux, A., Fiat, L., Gillet, C., Bony, S., 2011. Reproduction impairment following paternal genotoxin exposure 
in brown trout (Salmo trutta) and Arctic charr (Salvelinus alpinus). Aquat. Toxicol. 101, 405-411.

487

Devaux, A., Bony, S., Plenet, S., Sagnes, P., Segura, S., Suaire, R., Novak, M., Gilles, A., Olivier, J.M., 2015. Field evidence of reproduction impairment through sperm DNA damage in the fish nase (Chondrostoma nasus) in anthropized hydrosystems. Aquat. Toxicol. 169, 113-122.

Dévier, M.H., Le Dû-Lacoste, M., Akcha, F., Morin, B., Peluhet, L., Le Menach, K., Burgeot, T., Budzinski, H., 2013. Biliary PAH metabolites, EROD activity and DNA damage in dab (Limanda limanda) from Seine Estuary (France). Environ. Sci. Pollut. Res. 20, 708-722.

Erraud, A., Bonnard, M., Duflot, A., Geffard, A., Danger, J.M., Forget-Leray, J., Xuereb, B., 2018a. Assessment of sperm quality in palaemonid prawns using Comet assay: methodological optimization. Environ. Sci. Pollut. Res. 1-12.

Erraud, A., Bonnard, M., Chaumot, A., Geffard, O., Duflot, A., Forget-Leray, J., Le Foll, F., Geffard, A., Xuereb, B., 2018b. Use of sperm DNA integrity as a marker for exposure to contamination in Palaemon serratus (Pennant 1777): Intrinsic variability, baseline level and in situ deployment. Water Res. $132,124-134$.

Flammarion, P., Devaux, A., Nehls, S., Migeon, B., Noury, P., Garric, J., 2002. Multibiomarker responses in fish from the Moselle River (France). Ecotoxicol. Environ. Saf. 51, 145-153.

Flammarion, P., Garric, J., 1997. Cyprinids EROD activities in low contaminated rivers : A relevant statistical approach to estimate reference levels for EROD biomarker? Chemosphere 35, 2375-2388.

Frasco, M.F., Fournier, D., Carvalho, F., Guilhermino, L., 2008. Does mercury interact with the inhibitory effect of dichlorvos on Palaemon serratus (Crustacea: Decapoda) cholinesterase? Sci. Total Environ. 404, 8893.

González-Ortegón, E., Pascual, E., Cuesta, J.A., Drake, P., 2006. Field distribution and osmoregulatory capacity of shrimps in a temperate European estuary (SW Spain). Estuar. Coast. Shelf Sci. 67, 293-302.

Hagger, J.A., Jones, M.B., Lowe, D., Leonard, D.R.P., Owen, R., Galloway, T.S., 2008. Application of biomarkers for improving risk assessments of chemicals under the Water Framework Directive: A case study. Mar. Pollut. Bull. 56, 1111-1118.

Hanson, N., Förlin, L., Larsson, Å., 2010. Spatial and annual variation to define the normal range of biological 
514 Hanson, N., 2011. Using biological data from field studies with multiple reference sites as a basis for environmental management: The risks for false positives and false negatives. J. Environ. Manage. 92, 610_

Grosbois, C., Meybeck, M., Horowitz, A., Ficht, A., 2006. The spatial and temporal trends of $\mathrm{Cd}, \mathrm{Cu}, \mathrm{Hg}, \mathrm{Pb}$ and $\mathrm{Zn}$ in the Seine river floodplain deposits (1994-2000). Sci. Total Environ. 356, 22-37.

ICES., 2011. Report of the Study Group on Integrated Monitoring of Contaminants and Biological Effects (SGIMC), 14-18 March 2011, Copenhagen, Denmark. ICES CM 2011/ACOM:30. 265 pp. Vitellogenin-like protein measurement in caged Gammarus fossarum males as a biomarker of endocrine disruptor exposure: Inconclusive experience. Aquat. Toxicol. 122-123, 9-18.

Key, P.B., Wirth, E.F., Fulton, M.H., 2006. A Review of Grass Shrimp, Palaemonetes spp., as a Bioindicator of Anthropogenic Impacts. Environ. Bioindic. 1, 115-128.

Lacaze, E., Geffard, O., Bony, S., Devaux, A., 2010. Genotoxicity assessment in the amphipod Gammarus fossarum by use of the alkaline Comet assay. Mutat. Res. - Genet. Toxicol. Environ. Mutagen.

Lacaze, E., Devaux, A., Jubeaux, G., Mons, R., Gardette, M., Bony, S., Garric, J., Geffard, O., 2011a. DNA damage in Gammarus fossarum sperm as a biomarker of genotoxic pressure: Intrinsic variability and reference level. Sci. Total Environ. 409, 3230-3236.

Lacaze, E., Geffard, O., Goyet, D., Bony, S., Devaux, A., 2011b. Linking genotoxic responses in Gammarus fossarum germ cells with reproduction impairment, using the Comet assay. Environ. Res. 111, $626-634$.

Le Goff, J., Gallois, J., Pelhuet, L., Devier, M.H., Budzinski, H., Pottier, D., André, V., Cachot, J., 2006. DNA adduct measurements in zebra mussels, Dreissena polymorpha, Pallas: Potential use for genotoxicant biomonitoring of fresh water ecosystems. Aquatic Toxicology. 79, 55-64. 
Lewis, C., Galloway, T., 2010. Sperm toxicity and the reproductive ecology of marine invertebrates. Integr. Environ. Assess. Manag. 6, 188-189.

Liepelt, A., Karbe, L., Westendorf, J., 1995. Induction of DNA strand breaks in rainbow trout Oncorhynchus mykiss under hypoxic and hyperoxic conditions. Aquat. Toxicol. 33, 177-181.

Ling, S. W., 1967. The general biology and development of Macrobruchium rosenbergii (de Man). FAO Wildl. Sri. Conf: Biol. Culi. Shrimps Prawns. 30, 1-18.

Lobry, J., Lepage, M., Rochard, E., 2006. From seasonal patterns to a reference situation in an estuarine environment: Example of the small fish and shrimp fauna of the Gironde estuary (SW France). Estuar. Coast. Shelf Sci. 70, 239-250.

Marchand, J., Quiniou, L., Riso, R., Thebaut, M.T., Laroche, J., 2004. Physiological cost of tolerance to toxicants in the European flounder Platichthys flesus, along the French Atlantic Coast. Aquat. Toxicol. 70, $327-343$.

Menezes, R.R., Campos, L.F., De Neves, G.A., Ferreira, H.C., 2006. Biomarker responses of the estuarine brown shrimp Crangon crangon L. to non-toxic stressors: Temperature, salinity and handling stress effects. J. Exp. Mar. Bio. Ecol. 52, 114-124.

Meybeck, M., Horowitz, A.J., Grosbois, C., 2004. The geochemistry of Seine River Basin particulate matter: Distribution of an integrated metal pollution index. Sci. Total Environ. 328, 219-236.

Motelay-Massei, A., Ollivon, D., Garban, B., Tiphagne-Larcher, K., \& Chevreuil, M., 2007. Fluxes of polycyclic aromatic hydrocarbons in the Seine estuary, France: mass balance and role of atmospheric deposition. Hydrobiologia, 588(1), 145-157.

Mustafa, S.A., Al-Subiai, S.N., Davies, S.J., Jha, A.N., 2011. Hypoxia-induced oxidative DNA damage links with higher level biological effects including specific growth rate in common carp, Cyprinus carpio L. Ecotoxicology. 20, 1455-1466.

Ohe, T., Watanabe, T., Wakabayashi, K., 2004. Mutagens in surface waters: A review. Mutat. Res. - Rev. Mutat. Res. 567, 109-149.

Rank, J., Lehtonen, K.K., Strand, J., Laursen, M., 2007. DNA damage, acetylcholinesterase activity and lysosomal stability in native and transplanted mussels (Mytilus edulis) in areas close to coastal chemical 
dumping sites in Denmark. Aquat. Toxicol. 84, 50-61.

Romero, E., Le Gendre, R., Garnier, J., Billen, G., Fisson, C., Silvestre, M., Riou, P., 2016. Long-term water quality in the lower Seine: Lessons learned over 4 decades of monitoring. Environ. Sci. Policy 58, 141-

Sanchez, W., Piccini, B., Ditche, J.M., Porcher, J.M., 2008. Assessment of seasonal variability of biomarkers in three-spined stickleback (Gasterosteus aculeatus L.) from a low contaminated stream: Implication for environmental biomonitoring. Environ. Int. 34, 791-798.

Santos, R., Palos-ladeiro, M., Besnard, A., Porcher, J.M., Bony, S., Sanchez, W., Devaux, A., $2013 a$. Relationship between DNA damage in sperm after ex vivo exposure and abnormal embryo development in the progeny of the three-spined stickleback. Reprod. Toxicol. 36, 6-11.

Santos, R., Palos-Ladeiro, M., Besnard, A., Reggio, J., Vulliet, E., Porcher, J.M., Bony, S., Sanchez, W., Devaux, A., 2013b. Parental exposure to methyl methane sulfonate of three-spined stickleback: Contribution of DNA damage in male and female germ cells to further development impairment in progeny. Ecotoxicology. 22, 815-824.

Singh, R., Hartl, M.G., 2012. Fluctuating estuarine conditions are not confounding factors for the Comet assay assessment of DNA damage in the mussel Mytilus edulis. Ecotoxicol. 21, 1998-2003.

Singh, N.P., McCoy, M.T., Tice, R., Schneider, E.L., 1988. A simple technique for quantitation of low levels of DNA damage in individual cells. Exp. Cell Res. 175 (1), 184-191.

Subramoniam, T., 2016. Sexual Biology and Reproduction in Crustaceans. Academic Press/Elsevier, 528 pp.

Vicquelin, L., Leray-Forget, J., Peluhet, L., LeMenach, K., Deflandre, B., Anschutz, P., Etcheber, H., Morin, B., Budzinski, H., Cachot, J., 2011. A new spiked sediment assay using embryos of the Japanese medaka specifically designed for a reliable toxicity assessment of hydrophobic chemicals. Aquat. Toxicol. 105, $235-245$.

Vincent-Hubert, F., Uher, E., Di Giorgio, C., Michel, C., De Meo, M., Gourlay-France, C., 2017. Use of low density polyethylene membranes for assessment of genotoxicity of PAHs in the Seine River. Ecotoxicology 26, 165-172.

Webb, D., Gagnon, M.M., 2013. Depurated fish as an alternative reference for field-based biomarker monitoring. 
Environ. Monit. Assess. 185, 1331-1340.

595 Wu, R. S., Siu, W. H., Shin, P. K., 2005. Induction, adaptation and recovery of biological responses: implications for environmental monitoring. Mar. Pollut. Bull. 51(8-12), 623-634.

597 Xuereb, B., Chaumot, A., Mons, R., Garric, J., Geffard, O., 2009. Acetylcholinesterase activity in 598 Gammarus fossarum (Crustacea Amphipoda). Intrinsic variability, reference levels, and a reliable tool for field surveys. Aquat. Toxicol. 93, 225-233. 
ACCEPTED MANUSCRIPT

\begin{tabular}{|c|c|c|c|c|c|}
\hline SAMPLING DATES & SITES & $\mathrm{T}^{\circ} \mathrm{C}$ & SALINITY & DISSOLVED OXYGEN (PPM) & DISSOLVED OXYGEN (\%) \\
\hline \multirow[t]{8}{*}{$16 / 04 / 2015$} & NB1 & 12.7 & 14 & ND & ND \\
\hline & NB2 & 12.5 & 16 & ND & ND \\
\hline & NB3 & 12.6 & 12 & ND & ND \\
\hline & Ri1 & 12.7 & 10 & ND & ND \\
\hline & RiR & ND & ND & ND & ND \\
\hline & $\mathrm{Ri} 2$ & 12.9 & 8 & ND & ND \\
\hline & TB1 & 13.1 & 6 & ND & ND \\
\hline & TB2 & 13.3 & 3 & ND & ND \\
\hline \multirow[t]{8}{*}{$21 / 01 / 2016$} & NB1 & 5.7 & 17 & ND & ND \\
\hline & NB2 & 5.7 & 15 & ND & ND \\
\hline & NB3 & 5.7 & 12 & ND & ND \\
\hline & Ri1 & 5.8 & 9 & ND & ND \\
\hline & RiR & 5.9 & 10 & $\sqrt{-1}$ & ND \\
\hline & $\mathrm{Ri} 2$ & 5.7 & 8 & ND & ND \\
\hline & TB1 & 5.8 & 8 & ND & ND \\
\hline & TB2 & 5.8 & 7 & ND & ND \\
\hline \multirow[t]{8}{*}{$13 / 05 / 2016$} & NB1 & 14.3 & 11 & 5.88 & 82.3 \\
\hline & NB2 & 14.8 & 9 & 6.46 & 80.4 \\
\hline & NB3 & 14.7 & 7 & 5.27 & 79.6 \\
\hline & Ri1 & 14.1 & 6 & 5.17 & 76.5 \\
\hline & RiR & 14.5 & 5 & 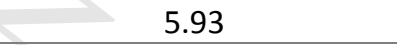 & 81.4 \\
\hline & $\mathrm{Ri} 2$ & 14.3 & 5 & 5.15 & 78.3 \\
\hline & TB1 & 14.1 & 4 & 6.2 & 79.0 \\
\hline & TB2 & 14.7 & 3 & 5.61 & 80.0 \\
\hline \multirow[t]{8}{*}{$25 / 10 / 2016$} & NB1 & 13.7 & 25 & 7.21 & 81.4 \\
\hline & NB2 & 13.1 & 19 & 7.52 & 83.6 \\
\hline & NB3 & 12.8 & 16 & 7.34 & 82.5 \\
\hline & Ri1 & 12.9 & 14 & 7.63 & 86.8 \\
\hline & RiR & 12.7 & 5 & 8.02 & 90.2 \\
\hline & Ri2 & 12.9 & 6 & 7.83 & 87.4 \\
\hline & TB1 & 13.0 & 5 & 7.65 & 85.9 \\
\hline & TB2 & 12.9 & 4 & 7.47 & 81.7 \\
\hline \multirow[t]{8}{*}{$17 / 04 / 2017$} & NB1 & 12.5 & 14 & 8.60 & 92.0 \\
\hline & NB2 & 12.5 & 13 & 8.70 & 95.8 \\
\hline & NB3 & 12.4 & 12 & 8.20 & 90.6 \\
\hline & Ri1 & 12.5 & 10 & 8.17 & 90.1 \\
\hline & RiR & 13.2 & 4 & 8.58 & 92.0 \\
\hline & Ri2 & 12.9 & 6 & 7.83 & 88.0 \\
\hline & TB1 & 13.1 & 3 & 8.02 & 90.0 \\
\hline & TB2 & 13.1 & 3 & 7.99 & 88.0 \\
\hline \multirow[t]{8}{*}{$25 / 10 / 2017$} & NB1 & 14 & 19 & 6.95 & 85.3 \\
\hline & NB2 & 13.9 & 17 & 7.58 & 83.1 \\
\hline & NB3 & 13.7 & 16 & 7.21 & 83.2 \\
\hline & Ri1 & 13.6 & 15 & 7.64 & 84.4 \\
\hline & RiR & 14.3 & 6 & 8.01 & 89.5 \\
\hline & Ri2 & 14 & 7 & 7.73 & 87.2 \\
\hline & TB1 & 14.2 & 10 & 7.54 & 82.2 \\
\hline & TB2 & 14.3 & 6 & 7.61 & 83.9 \\
\hline
\end{tabular}




\section{Highlights}

- Alternative strategy to propose a baseline of sperm DNA integrity in P. longirostris

- Persistence of sperm DNA damages during 20 days after the toxic stress cancelation

- Relevance of a significant threshold to discriminate abnormal genotoxic pressure 